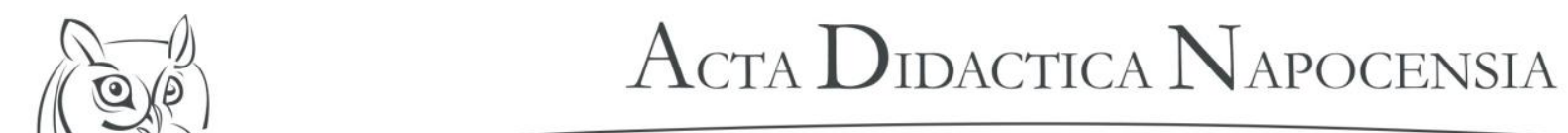

Volume 11, Number 1, 2018

\title{
THE RELATIONSHIP AMONG INFORMATION AND COMMUNICATION TECHNOLOGY UTILIZATION, SELF-REGULATED LEARNING AND ACADEMIC PERFORMANCE OF PROSPECTIVE TEACHERS
}

\author{
ONIVEHU Adams Ogirima, ADEGUNJU Adewale Kabir, OHAWUIRO Emilia Onyinyechi, \\ OYENIRAN Juliana Bunmi
}

\begin{abstract}
This study investigated the relationship among Information Communication Technology utilization, self-regulated learning and academic performance of prospective teachers. The ex-post facto design (correlation method) was employed for the study. The research subjects were 580 prospective teachers who were drawn using multi-stage sampling technique from University of Ilorin, Nigeria. Seven research questions were generated while four hypotheses were tested at 0.05 level of significance. A researcher-constructed questionnaire tagged "Information Communication Technology Utilization and Self-Regulated Learning Questionnaire (ICTUSRLQ)" was used for data collection. The instrument was administered on 60 selected prospective teachers outside the sample location through test-retest method; it yielded a reliability coefficient of 0.79 that was obtained through the Cronbach's Alpha formula. Data were analysed with percentage, mean and rank order, $t$-test, Pearson Product Moment Correlation and multiple regression statistical tools. The findings revealed that prospective teachers have a high level of ICT utilization, self-regulation and academic performance; gender did not influence prospective teachers' ICT utilization, selfregulation and academic performance; there was a significant relationship between Information Communication Technology utilization and self-regulated learning and that there was a significant composite relationship among ICT utilization, self-regulation (elaboration, organization, critical thinking, metacognition, peer learning and help seeking) and academic performance of prospective teachers. The researchers recommended that self-regulation training and ICT competence capacity building workshops should be organized for prospective teachers in University of Ilorin.
\end{abstract}

Keywords: Information and Communication Technology, Self-Regulated Learning, Academic Performance, Prospective Teachers

\section{Introduction}

The sustainable development of any nation is essentially premised on the knowledge, character and skills, of its human resources. Recognizing this fact, the United Nations Development Programme (UNDP, 2017) has stressed the importance of education as an indispensable tool for fostering the development of human resources for the sustainable development of nations. In this sense, therefore, education is an enterprise that has attracted substantial investment from many nations in Sub-Saharan Africa till date. In Nigeria for instance, education has been widely recognized and adopted as an indispensable tool for fostering national development. Essentially, the Nigerian philosophy of

Cite as: Onivehu, A. O.; Adegunju, A. K.; Ohawuiro, E. O.; \& Oyeniran, J. B. (2018). The Relationship among ICT Utilization, SRL and Academic Performance of Prospective Teachers, Acta Didactica Napocensia, 11(1), 69-85. DOI: 10.24193/adn.11.1.6. 
education stresses the importance of providing equal educational opportunities for all citizens of the nation at the primary, secondary and tertiary levels. Indeed, these different levels of education have been designed to cater for different needs of individuals and the nation at large. For instance, tertiary education is basically deployed by several Monotechnics, Polytechnics, Colleges of Education, Universities and a host of other post-secondary institutions that are located across the length and breadth of the country. More so, there is a broad range of extant and emerging Federal, State and Private universities in Nigeria that have been licensed to offer many courses as accredited by the National Universities Commission (NUC).

On the whole, the National Policy on Education (2013) stipulates that university education shall make optimum contribution to national development by offering and tailoring its programmes to foster development of adequate human resources in line with the peculiar needs of the nation. Hence, in order to ascertain whether or not the goals of university education are being achieved, there is no question that students' academic performance remains an essential yardstick for assessing the relative effectiveness of university education in Nigeria. That is, the way students perform in any chosen course of study is a common benchmark that parents, lecturers, administrators, policy makers and the generality of the society adopt for evaluating the success or failure of universities in Nigeria (Adegunju, Onivehu, Oyeniran \& Odetunde, 2017). To this end, educationists have been concerned with factors that play a role in students' academic performance for decades. Particularly, with regard to factors that mediate students' performance in our contemporary world, Information Communication Technology utilization and self-regulated learning have been thoroughly researched. Information Communication Technology as implied in this context is an umbrella term that covers any product that will store, retrieve, manipulate, transmit or receive information electronically in a digital form. It encompasses all hardware, software, networks and media for collection, storage, processing, transmission and presentation of information (voice, data, texts and images) (Arinze, Okonkwo \& Iwunor, 2012). ICT also includes computers sets, computer and application software (that is spreadsheet, word processing, excel), disc and storage media (that is memory cards, flash drives, scanner , CD-ROMs, audio and video cassettes, films, picture, e-books, e-magazines), telecommunication gadget and services such as web-based tools, mobile technologies and abroad spectrum of extant and emerging technologies that are used for processing, storage, presentation, communication and exchange of data and information (Bebetsos\& Antoniou, 2008; Barrow, Markman\& Rouse, 2009). In the field of education, effective utilization of ICT tools for instructional process reinforces the teacher's ability to cater for individual differences and fosters learners' involvement, participation and understanding (Hussain, Iqbal, \& Akhtar, 2010). Similarly, Bhukuvhani, Zezekwa and Sunzuma (2011) noted that the integration of ICT into the teachinglearning process facilitates the quality of education. Supporting the foregoing, Saffari, Takmil and Arabzadeh (2014) noted that ICTs makes learning to take place in a collaborative, independent and self-directed manner. That is to say that, teaching and learning is significantly improved when ICT tools are properly harnessed by lecturers and students. Likewise, undergraduate students stand to gain maximally from leveraging the potentials of ICTs for academic purposes. For instance, several ICT tools such as communication tools (WhatsApp, Skype, Google Talk); Social Networks (Twitter, Facebook); repositiories (Instagram, YouTube, Slideshare) and storage tools ( wikis and blogs) have been found to be commonly used for academic and non-academic purposes among university students ( Yot-Domonguez\& Marcelo, 2017). Hence, in line with these findings, a plethora of empirical studies have found that ICTs have a positive impact on students' performance. For instance, a study conducted by Balanskat, Anja, Roger and Kefala (2006) found thatICT improves competency development, team work, independent learning and higher order thinking skills among students in Europe.In like manner, Onyia (2013) found that ICT significantly impacts students' academic studies in university of Nigeria Nsukka. Likewise, Salako, Solomon and Adepoju (2015) found that there was positive perception of computer utilization on students' academic performance in selected Colleges of Education in North Central geopolitical zone of Nigeria. Similarly, Mohammed and Abdulghani (2017) found that there was a positive relationship between students' use of technology and achievement in physiology courses in selected health colleges of the University of Dammam. Nevertheless, findings on the relationship between ICT utilization and students' performance are somewhat contradictory as some studies have indicated. In this wise, Cruz-Jesus, Vicente, Bacao and 
Oliveira (2016) found that there is a minute and inconsistent evidence of impact of ICT integration on students' performance in Europe. Similarly, Mbaeze, Ukwandu and Anudu (2010) found that there was no statistically significant relationship between ICTs and students' academic performance in Nigeria. In a similar vein, Chiraz (2016)found a distinctive, though negative, effect of ICT on performance in Tunisian higher education. Babaheidari and Svensson (2014) in another study noted that the impact of ICT on learning outcomes is not clear. Likewise, the findings of Shamim, Jahangir and Ariful (2015) indicated that there is no significant relationship between the use of ICT and the performance of the students in private and public universities in Bangladesh. Given the pervasiveness of social networking in our contemporary world, a plethora of studies also indicated a negative relationship between social-networking site use and academic performance (Stollak, Vandenberg, Burklund, \& Weiss, 2011; Rosen, Carrier, \& Cheever, 2013).

Based on the foregoing, it is conceivable that the utilization of ICTs by students is a coin with two sides. On the one hand, there are significant improvements in students' academic performance when ICTs are harnessed for academic-oriented purposes. On the other hand, ICTs may negatively impact students' academic performance when they are used for non-academic purposes that may distract students' attention from important academic tasks and activities. That is to say, productive usage of ICTs is directly related to positive results for students, if its potentials are properly controlled and channeled for academic ends. By and large, it therefore follows that the degree of moderation or control that a student has on the use of ICTs may be a significant determinant of how undergraduate students learn and perform. In other words, self-regulation of learning is of great importance to students' academic performance vis a vis the way students learn and integrate ICT tools in the learning process. In broad terms, self-regulation is a multidimensional concept that defies a singular definition because of the complex interplay of paradigms, domains, strategies and constructs that constitutes the process of learning. Nevertheless, self-regulation means the extent to which a student is able to exercise control over his or her cognition, emotion and behaviour so as to meet predetermined expectations or the peculiar demands of a situation. The essence of self-regulated learning is premised on the ability and competence of students to independently and collaboratively act to modify learning experiences and processes based on a set of effective strategies (Schunk \& Zimmerman, 2008). Thus, self-regulated learners have a specific set of study habits and learning strategies that are constantly practiced on a daily basis in order to critically think and proactively act upon the essential tasks and activities of the learning environment. In other words, self-regulated learners maintain a high degree of independent direction, control, discipline, and resilience when dealing with academic processes (Tavakolizadeh \& Ebrahimi-Qavam, 2011). Hence, there is a consensus among experts that selfregulated learners adopt a broad range of strategies that are germane to the process of making a comprehensive meaning and understanding out of diverse experiences in any learning context. In this sense,self-regulated learners utilize memory strategy, goal setting, self-evaluation, help seeking, environmental structuring, learning responsibility, planning, repetition, rehearsal, elaboration, organization, critical thinking, peer learning and a host of others to maximize the potentials of learning for better academic performance. In other words, extant literature indicates that the ability of students to effectively adopt the aforementioned strategies is of great importance to the way students perform in the teaching-learning process. For instance, Al-Khatib (2010) found that self-regulated learning significantly predicted students' academic performance in selected colleges in the United Arab Emirates. Similarly, the findings of Muhammed and Abubakar (2015) indicated that there is a significant relationship between SRL and academic achievement among undergraduate students in Malaysia. In China, Peng (2012) also found a significant relationship between SRL and students' achievement in science. Fadlelmula, Cakiroglu and Sungur (2015) also found a significant relationship among motivational beliefs, self-regulated learning strategies, and achievement in mathematics. In Saudi Arabia, Alotaibi, Tohmaz and Jabak (2017) found that there was a positive and significant relationship between self-regulated learning and students' academic achievement at King Saud University. Nevertheless, findings remain inconclusive on the relationship between self-regulation and students' performance. In this regard, Loong (2012) found that there was no significant relationship between self-regulated learning strategies and Mathematics performance of pre-university students in Malaysia. In a similar vein, self-regulated learning has also been linked to ICT utilization among undergraduate students. In line with the foregoing, Seyedeh and Masoud (2014) found that there is a 
direct relationship between ICT and self-regulation among undergraduate students of Islamic Azad University of Sari. In India, Kute and Pote-Palsamkar (2015) found a significant relationship between the self-regulated learning and internet usage of Commerce, Science and Arts undergraduates in university of Mumbai. In Thailand, Samruayruen, Enriquez, Natakuatoong, and Samruayruen (2013) found that online learners have high levels of self-regulation.

Furthermore, empirical evidence indicates that the relationship ICT utilization, self-regulation and students' academic performance is somewhat mediated by gender. That is to say, there may be variations in the way male students and their female counterparts utilize ICT tools for academicoriented and non-academic oriented purposes. By the same token, the self-regulation strategies adopted by students may differ by gender. Thus, it therefore follows that male and female prospective teachers may perform differently after being exposed to the same teaching-learning process for a given period of time. Specifically, Peter and Valkenburg (2009) found that male students tend to benefit more from the use of ICTs than their female counterparts. In another study, Beena (2012) found that male students have shown higher awareness as compare to female students towards the use of ICT in education. Conversely, the experimental study carried out by Efuwape, and Ayotola (2013) found a no significant gender difference in both acceptability and usability of a computer package by students in a University and Polytechnic in Ogun State, Nigeria. Similarly, Chama and Sanjay (2016) found that gender did not play a role in students and faculty opinions towards ICT use in Indian universities. In relation to the influence of gender on the level of self-regulation among students, the findings of AlAsmari and Ismail (2012) revealed significant differences in the self-regulated learning of undergraduate students in a Saudi Arabia university. Likewise, the findings of Bidjerano (2005) indicated that female students surpassed male students in their ability to use rehearsal, organization, metacognition, time management skills, elaboration and effort as self-regulated strategies, but, there were no statistically significant gender differences withrespect to peer learning, critical thinking skills and help seeking. On the whole, gender is a moderating variable that has been found to mediate students' academic performance in extant literature. In this sense, findings are inconsistent due to the fact that some studies carried out by Mlambo (2011), Abdu-Raheem (2012), Josiah and Adejoke (2014) revealed no significant differences in the academic performance of male and female students. Conversely, some other studies indicate that there is a significant difference between the academic performance of male students and their female counterparts (Awofala, 2011;Voyer\&Voyer, 2014; Oluwagbohunmi, 2014). In the light of the foregoing, therefore, it is apparent that there is a need for more empirical studies to explore the nature of the relationship that may exist among Information Communication Technology utilization, self-regulated learning and prospective teachers' academic performance. To this end, the present study investigated the relationship among Information Communication Technology utilization, self-regulated learning and academic performance of prospective teachers in University of Ilorin, Nigeria.

\subsection{Problem}

Teachers play a central role as prime implementers of the curriculum in the teaching-learning process across the main levels of formal education in any nation, Nigeria inclusive. As a consequence, therefore, the academic performance of prospective teachers in Nigerian teacher training institutions is of great importance in order to maintain an effective and efficient educational system in line with global best practices. In this sense, a broad spectrum of factors and variables has been empirically linked to students' academic performance. For instance, the researchers have observed that prospective teachers in University of Ilorin utilize ICT facilities for academic and non-academic purposes on a daily basis. Thus, given that utilization of ICT may either make or break students' performance if some degree of self-regulation is not exercised, it is conceivable that the findings of extant studies remain contradictory and disparate on the relationship among ICT utilization, self-regulated learning and students' academic performance (Mbaeze, Ukwandu\&Anudu, 2010; Loong, 2012; Onyia, 2013; Babaheidari \& Svensson, 2014; Muhammed \&Abubakar; 2015, Shamim, Jahangir \& Ariful, 2015; Mohammed \& Abdulghani, 2017). More so, there remains a paucity of related studies on the relationship among ICT utilization, self-regulated learning and academic performance of prospective teachers in the Nigerian setting. In order to fill this gap, the problem of the present study was to 
investigate the relationship among Information Communication Technology utilization, self-regulated learning and academic performance among prospective teachers in University of Ilorin, Nigeria.

\subsection{Research Questions}

The prime purpose of this study is to investigate the relationship among Information Communication Technology utilization, self-regulated learning and academic performance of prospective teachers in University of Ilorin, Nigeria. Specifically, the study seeks to investigate:

1. the extent of Information Communication Technology utilization among prospective teachers in University of Ilorin Nigeria;

2. the level of self-regulated learning among prospective teachers in University of Ilorin, Nigeria;

3. the level of academic performance among prospective teachers in University of Ilorin, Nigeria;

4. the influence of gender on the level of Information and Communication Technology utilization among prospective teachers in University of Ilorin Nigeria;

5. the influence of gender on the level of academic performance among prospective teachers in University of Ilorin, Nigeria;

6. the influence of gender on the level of self-regulated learning among prospective teachers in University of Ilorin, Nigeria;

7. the relationship between Information and Communication Technology utilization and selfregulated learning among prospective teachers in University of Ilorin, Nigeria; and

8. the composite relationship among Information and Communication utilization, self-regulated learning and academic performance of prospective teachers in University of Ilorin, Nigeria.

\subsection{Research Hypotheses}

1. There is no significant difference in the extent of utilization of Information and Communication Technology among prospective teachers in University of Ilorin based on gender.

2. There is no significant difference in the level of academic performance among prospective teachers in University of Ilorin, Nigeria based on gender.

3. There is no significant difference in the level of self-regulated learning among prospective teachers in University of Ilorin, Nigeria based on gender.

4. There is no significant relationship between Information and Communication Technology utilization and self-regulated learning of prospective teachers in University of Ilorin, Nigeria.

5. Information and Communication Technology and self-regulated learning will not significantly predict the academic performance of prospective teachers in University of Ilorin, Nigeria.

\section{Method}

The research design adopted for this study is the correlational method of the ex-post facto research because the study is concerned with investigating the relationship that exists between a dependent variable (academic performance) and two independent variables (Information and communication technology utilization and self-regulated learning) without manipulation and randomization of variables (Ary, Jacobs, Razavieh \& Sorensen, 2009). The population for this study was all prospective teachers in University of Ilorin, Nigeria. Five hundred and eighty (580) prospective teachers were drawn from a population of about 3,500 prospective teachers in the second year, third year and fourth year of study respectively using multi-stage sampling technique. The respondents were selected from various departments in the Faculty of Education, University of Ilorin. These include Adult and Primary Education, Arts Education, Educational Management, Counsellor Education, Educational Technology, Health Promotion \& Environmental Health Education, Human Kinetics Education, Science Education and Social Sciences Education. 
The main instrument for collecting the required information for the study was a self-designed questionnaire tagged "Information and Communication Technology Utilization and Self-Regulated Learning Questionnaire (ICTUSRLQ)". Section A sought demographic information and self-reported Cumulative Grade Point Average of the respondents. Section B with 15 items focused on prospective teachers' utilization of Information and Communication Technology. Section C with 34 items on elaboration, organization, critical thinking, metacognition, peer learning and help seeking that were adopted from the Motivated Strategies for Learning Questionnaire (MSLQ). Section B was patterned in Likert scale format of Very Often $(\mathrm{VO})=4$ points, Often Used $(\mathrm{OU})=3$ points, Rarely Used $(\mathrm{RU})=$ 2 points, and Never Used $(\mathrm{NU})=1$ point. Items in Section $\mathrm{C}$ were patterned in a seven point Likert scale format of Very True $(\mathrm{VT})=7$ points, Somehow True $(\mathrm{ST})=6$ points, A little true $(\mathrm{LT})=5$ points, Neither True or False $(\mathrm{NTF})=4$ points, Slightly True $(\mathrm{SLT})=3$ points, Not True $(\mathrm{NT})=2$ points and Not True at All $(\mathrm{NTA})=1$ point. For the purpose of this study, respondents who scored 34-102 points were considered as having a low level of self-regulation, the respondents who scored 103-171 points were adjudged to have an average level of self-regulation while respondents who scored 172-238 were taken as prospective teachers with a high level of selfregulation. The current CGPA of respondents were collected and scored as follows; high academic performance $=3.5-5.0$ average academic performance $=2.5-3.49$ and low academic performance $=$ 1.5- 2.49 .

The content validity of the instrument used in this study was established through three experts in the Faculty of Education, University of Ilorin. The experts did the necessary corrections which were used to produce the final version used for the study. The internal consistency of the instrument (ICTUSRLQ) was established by using Cronbach's Alpha. Thus, the reliability of 0.79 was obtained which was considered very high and thus reliable for the study. The data obtained was analyzed using different statistical measures which include percentages, summated mean ranking, t-test and multiple regression.

\section{Results}

Table 1 shows respondents' gender, out of 580 respondents that were sampled, $260(44.8 \%)$ of the respondents were males while $320(55.2 \%)$ were females. Table 2 shows that $325(56 \%)$ of the respondents are 200 level students, 195 (33.6\%) of the respondents are 300 level students, 60(10.3\%) of the respondents are in 400 level while 45(7.76\%) of the respondents are Adult and Primary Education students, 37(6.38\%) of the respondents are Arts Education students, 68(11.72\%) of the respondents are Educational Management students. 100 (17.24\%) of the respondents are Counsellor Education students, 58(10.0\%) of the respondents are Educational Technology students, 72(12.42\%) of the respondents are Health Promotion and Environmental Health Education students, 42(7.24\%) of the respondents are Human Kinetics Education students, 80(13.79\%) of the respondents are Science Education students while 78(13.45\%) of the respondents are Social Sciences Education students.

Table 1: Demographic Distribution of Respondents by Gender

\begin{tabular}{|c|c|c|}
\hline Gender & Frequency & Percentage (\%) \\
\hline Male & 260 & 44.80 \\
Female & 320 & 55.20 \\
Total & $\mathbf{5 8 0}$ & $\mathbf{1 0 0 . 0}$ \\
\hline
\end{tabular}

Table 2: Demographic Distribution of the Respondents by Academic Level

\begin{tabular}{|c|c|c|}
\hline Academic Level & Frequency & Percentage (\%) \\
\hline Second year of study & 325 & 56.00 \\
Third year of study & 195 & 33.60 \\
Fourth year of study & 60 & 10.30 \\
Total & $\mathbf{5 8 0}$ & $\mathbf{1 0 0 . 0}$ \\
\hline
\end{tabular}


Table 3: Demographic Distribution of the Respondents by Department

\begin{tabular}{|c|c|c|}
\hline Department & Frequency & Percentage $(\%)$ \\
\hline Adult and Primary Education & 45 & 7.76 \\
\hline Arts Education & 37 & 6.38 \\
\hline Educational Management & 68 & 11.72 \\
\hline Counsellor Education & 100 & 17.24 \\
\hline Educational Technology & 58 & 10.00 \\
\hline Health Promotion \& Environmental Health Education & 72 & 12.42 \\
\hline Human Kinetics Education & 42 & 7.24 \\
\hline Science Education & 80 & 13.79 \\
\hline Social Sciences Education & 78 & 13.45 \\
\hline Total & 580 & 100.0 \\
\hline
\end{tabular}

Research Question 1:

What is the extent of Information and Communication Technology utilization among prospective teachers in University of Ilorin?

Table 4: $\quad$ Means and standard deviation scores of prospective teachers on extent of utilization of ICTs for academic-oriented and non-academic oriented purposes

\begin{tabular}{|l|c|c|}
\hline Items & Mean & SD \\
\hline Completion of assignments & 3.41 & 0.78 \\
Social Networking & 3.29 & 0.86 \\
Sending/receiving course materials & 3.24 & 0.72 \\
Corroboration with classmates on academic-related matters & 3.22 & 0.75 \\
Downloading learning materials & 3.09 & 0.81 \\
Accessing relevant academic-related information & 3.06 & 0.75 \\
Listening to music & 3.03 & 1.01 \\
Research-related activities & 2.93 & 0.88 \\
Gaming & 2.91 & 0.98 \\
Watching movies & 2.85 & 0.97 \\
News & 2.83 & 0.90 \\
Presentation of class work & 2.76 & 0.82 \\
Shopping & 2.21 & 1.00 \\
Gambling & 1.75 & 1.04 \\
\hline
\end{tabular}

Table 4 indicates the measure of central tendency and rank order analysis on the extent of utilization of Information and Communication Technology for academic-oriented and non-academic related purposes among prospective teachers in University of Ilorin. Thus, item 3 which states that "completion of assignments" ranked $1^{\text {st }}$ with a mean score of 3.41, item 14 which states that "social networking" ranked $2^{\text {nd }}$ with a mean score of 3.29 , item 5 which states that "sending/receiving course materials" ranked $3^{\text {rd }}$ with a mean score of 3.24 , item 4 which states that "corroboration with classmates on academic-related matters" ranked $4^{\text {th }}$ with a mean score of 3.22 , item 1 which states that "downloading learning materials" ranked $5^{\text {th }}$ with a mean score of 3.09, item 6 which states that "accessing relevant academic-related information" ranked $6^{\text {th }}$ with a mean score of 3.06 , item 9 which states that "listening to music" ranked $7^{\text {th }}$ with a mean score of 3.03. Furthermore, item 7 states that "research-related activities" ranked $8^{\text {th }}$ with a mean score of 2.93 , item 8 which states that "gaming" ranked $9^{\text {th }}$ with a mean score of 2.91 , item 10 which states that "watching movies" ranked $10^{\text {th }}$ with a mean score of 2.85 , item 13 which states that "news" ranked $11^{\text {th }}$ with a mean score of 2.83 , item 2 which states that "presentation of class work" ranked $12^{\text {th }}$ with a mean score of 2.76 , item 12 which states that "shopping" ranked $13^{\text {th }}$ with a mean score of 2.21 while item 12 which states that "gambling" ranked $14^{\text {th }}$ with a mean score of 1.75 . Based on these findings, it is deducible that the extent of utilization of ICTs for academic and non-academic purposes among the prospective teachers in University of Ilorin is high since 12 out of the 14 items had mean scores above the criteria weighted 
mean score of 2.50 set for high level of utilization of ICTs. However, the respondents indicated that ICTs are not used for shopping and gambling since these items have mean scores that were lower than the benchmark score of 2.50 adopted for the study.

Table 5: Distribution of Respondents by Levels of Academic Performance

\begin{tabular}{|c|c|c|}
\hline Levels of Academic Performance & Frequency & Percentage (\%) \\
\hline High & 345 & 59.5 \\
Average & 165 & 28.4 \\
Low & 70 & 12.1 \\
Total & $\mathbf{5 8 0}$ & $\mathbf{1 0 0 . 0}$ \\
\hline
\end{tabular}

Table 5 presents the level of academic performance among prospective teachers in University of Ilorin, Nigeria. Thus, 345(59.5\%) of the respondents were categorized as being high in academic performance, $165(28.4 \%)$ of the respondents were categorized as being average in academic performance while $70(12.1 \%)$ of the respondents were categorized as being low in academic performance.

Table 6: Distribution of Respondents by Levels of Self-regulated Learning

\begin{tabular}{|c|c|c|}
\hline Levels of Self-regulated Learning & Frequency & Percentage (\%) \\
\hline Low & 20 & 3.4 \\
Average & 139 & 24.0 \\
High & 421 & 72.6 \\
Total & $\mathbf{5 8 0}$ & $\mathbf{1 0 0 . 0}$ \\
\hline
\end{tabular}

Table 6 shows that 20(3.4\%) of the respondents rated themselves within the low level of self-regulated learning, $139(24.0 \%)$ of the respondents had average levels of self-regulated learning while $421(72.6 \%)$ of the respondents had high levels of self-regulation.

\section{Hypotheses Testing}

Hypothesis One:

There is no significant difference in the extent of Information and Communication Technology utilization among prospective teachers in University of Ilorin, Nigeria based on gender

Table 7: Mean, Standard Deviation and t-value on the extent of utilization of Information and Communication Technology among prospective teachers in University of Ilorin, Nigeria based on Gender

\begin{tabular}{|l|l|l|l|l|l|l|l|}
\hline Gender & No & Mean & SD & Df & $\begin{array}{l}\text { Cal .t- } \\
\text { value }\end{array}$ & $\begin{array}{l}\text { Crit. } \\
\text { t-value }\end{array}$ & P-value \\
\hline Male & 260 & 40.94 & 5.43 & 578 & 1.42 & 1.98 & 0.16 \\
\hline
\end{tabular}

As shown on Table 7, the calculated t-valuewas 1.42 while its critical t-value is $1.98(0.16>0.05$ level of significance). Since the calculated $t$-value is less than the critical value, the null hypothesis which states that there is no significant difference in the extent of Information and Communication Technology utilization among prospective teachers in University of Ilorin, Nigeria based on gender was not rejected. 
Hypothesis Two:

There is no significant difference in the level of academic performance among prospective teachers in University of Ilorin, Nigeria based on gender

Table 8: $\quad$ Mean, Standard Deviation and t-value on the level of academic performance among prospective teachers in University of Ilorin, Nigeria based on Gender

\begin{tabular}{|l|l|l|l|l|l|l|l|}
\hline Gender & No & Mean & SD & Df & $\begin{array}{l}\text { Cal .t- } \\
\text { value }\end{array}$ & $\begin{array}{l}\text { Crit. } \\
\text { t-value }\end{array}$ & P-value \\
\hline Male & 260 & 1.54 & 0.72 & 578 & 0.39 & 1.98 & 0.69 \\
Female & 320 & 1.52 & 0.69 & & & \\
\hline
\end{tabular}

As shown on Table 8, the calculated t-valuewas 0.39 while its critical t-value is $1.98(0.69>0.05$ level of significance). Since the calculated t-value is less than the critical value, the null hypothesis which states that there is no significant difference in the level of academic performance among prospective teachers in University of Ilorin, Nigeria based on gender was not rejected.

Hypothesis Three: $\quad$ There is no significant difference in the level of self-regulated learning among prospective teachers in University of Ilorin, Nigeria based on gender

Table 9: $\quad$ Mean, Standard Deviation and t-value on the level of self-regulated learning among prospective teachers in University of Ilorin, Nigeria based on Gender

\begin{tabular}{|l|l|l|l|l|l|l|l|l|}
\hline $\begin{array}{l}\text { Self- } \\
\text { Regulated } \\
\text { Learning }\end{array}$ & Gender & No & Mean & SD & $\begin{array}{l}\text { Cal. t- } \\
\text { value }\end{array}$ & $\begin{array}{l}\text { Crit. t- } \\
\text { value }\end{array}$ & P-value & Remarks \\
\hline Elaboration & Male & 260 & 33.15 & 6.11 & 2.45 & 1.98 & 0.14 & $* \mathrm{~S}$ \\
& Female & 320 & 34.36 & 5.59 & & & & \\
\hline Organization & Male & 260 & 20.85 & 4.72 & 2.36 & 1.98 & 0.19 & $* \mathrm{~S}$ \\
& Female & 320 & 21.73 & & & & & $\mathrm{NS}$ \\
\hline $\begin{array}{c}\text { Critical } \\
\text { thinking }\end{array}$ & Male & 260 & 25.83 & 5.99 & 1.56 & 1.98 & 0.12 & \\
\hline Metacognitive & Female & 320 & 25.06 & 5.80 & & & & $\mathrm{NS}$ \\
& Male & 260 & 62.33 & 12.21 & 0.73 & 1.98 & 0.46 & $\mathrm{NS}$ \\
\hline Peer learning & Female & 320 & 63.09 & 13.00 & & & & \\
& Male & 260 & 15.21 & 3.83 & 0.58 & 1.98 & 0.00 & \\
\hline Help seeking & Male & 320 & 15.00 & 4.82 & & & & $\mathrm{NS}$ \\
& Female & 320 & 19.96 & 4.85 & 0.25 & 1.98 & 0.35 & \\
\hline
\end{tabular}

df: 578; * S: Significant; NS: Not significant; 0.05 level of significance

From Table 9 it is seen that, in relation to the self-regulated learning strategies of prospective teachers, significant gender differences were found only with regard to elaboration $(t=2.45, \mathrm{df}=578, \mathrm{p}>0.05)$ and organization $(\mathrm{t}=2.36, \mathrm{df}=578, \mathrm{p}>0.05)$. However, since the mean scores for males and females on the strategies of elaboration and organization are higher than the criteria weighted mean score of 4.00 set for high level of self-regulation. That is, male prospective teachers and their female counterparts utilize elaboration and organization as strategies for learning with the females out-performing their male counterparts with higher mean. Nevertheless, no significant difference exists between male and female prospective teachers in their use of critical thinking, metacognitive strategies, peer learning and help seeking as self-regulated learning strategies (critical thinking, $\mathrm{t}=1.56$; metacognitive strategies, $\mathrm{t}$ $=0.73$; peer learning, $\mathrm{t}=0.58$; and help seeking, $\mathrm{t}=0.25$ ). On the whole, it is deducible from these findings that there is no significant difference in the level of self-regulated learning among prospective teachers in University of Ilorin based on gender. 
Hypothesis Four: There is no significant relationship between Information Communication Technology utilization and self-regulated learning among prospective teachers in University of Ilorin

Table 10: Analysis of the significant relationship between Information and Communication Technology utilization and self-regulated learning of prospective teachers in University of Ilorin

\begin{tabular}{|l|c|c|c|c|c|c|}
\hline \multicolumn{1}{|c|}{ Variables } & $\mathbf{N}$ & Mean & SD & Df & $\begin{array}{c}\text { r-calculated } \\
\text { value }\end{array}$ & $\begin{array}{c}\text { r-critical } \\
\text { value }\end{array}$ \\
\hline ICT utilization & 580 & 2.69 & 0.53 & 578 & 0.19 & 0.11 \\
Self-regulated learning & & 40.56 & 5.85 & & \\
\hline
\end{tabular}

As shown in Table 10, the $\mathrm{r}$-calculated value of 0.19 is greater than $\mathrm{r}$-critical value of 0.11 at 0.05 level of significance and for 578 degree of freedom. Hence, the null hypothesis is rejected. This means that there is a significant relationship between Information and Communication Technology utilization and academic performance of prospective teachers in University of Ilorin.

Hypothesis Five: There is no significant composite relationship among Information and Communication Technology utilization, self-regulated learning and academic performance of prospective teachers in University of Ilorin

Table 11: Multiple regression of the composite relationship between the predictor variables and Academic Performance of Prospective teachers in University of Ilorin

\begin{tabular}{|c|c|c|c|c|c|c|c|}
\hline Model & $\begin{array}{l}\text { Sum of } \\
\text { squares }\end{array}$ & Df & $\begin{array}{l}\text { Mean } \\
\text { squares }\end{array}$ & $\begin{array}{l}\text { Calculated } \\
\text { F-value }\end{array}$ & $\begin{array}{l}\text { Critical } \\
\text { F }\end{array}$ & Sig & Decision \\
\hline $\begin{array}{l}\text { Regression } \\
\text { Residual } \\
\text { Total }\end{array}$ & $\begin{array}{l}64.619 \\
219.993 \\
284.612\end{array}$ & $\begin{array}{r}8 \\
571 \\
579\end{array}$ & $\begin{array}{l}8.077 \\
0.385\end{array}$ & 20.965 & 3.00 & 0.000 & Rejected \\
\hline
\end{tabular}

*Significant at $\mathrm{p}<0.05$

Table 11 indicates that the calculated F-value is 20.965 while its calculated F- value is 3.00 with degree of freedom 8 and 571 computed at alpha level of 0.05 . Since the calculated f-value is greater than the critical value, the hypothesis which states that there is no significant composite relationship among Information and Communication Technology utilization, self-regulated learning and academic performance of prospective teachers in University of Ilorin was therefore rejected. In other words, there was a significant relationship among Information and Communication Technology utilization, self-regulated learning and the academic performance of prospective teachers in University of Ilorin. Thus, Information and Communication Technology utilization and self-regulated learning contributed greatly to the academic performance of prospective teachers in University of Ilorin, Nigeria. To examine the contributions of the independent variables which includes Information Communication Technology utilization (academic-oriented and non-academic oriented) and self-regulated learning (elaboration, organization, critical thinking, metacognitive, peer learning and help seeking), the Rsquare was computed and the output reveals thus:

Table 12: Model Summary of the Interactive relationship of Information and Communication Technology utilization and Self-regulation on Academic Performance of Prospective teachers in University of Ilorin

\begin{tabular}{|l|l|l|l|c|c|}
\hline Model & $\mathbf{R}$ & & R square & Adjusted R square & $\begin{array}{c}\text { Std Error of the } \\
\text { Estimate }\end{array}$ \\
\hline 1 & 0.476 & & 0.23 & 0.216 & 0.621 \\
\hline
\end{tabular}


The result in table 12 indicates that the both independents variables (ICT utilization and self-regulated learning) contributed $\mathrm{R}$ square of 0.23 representing $23 \%$ to the dependent variable (Academic performance of prospective teachers in University of Ilorin, Nigeria).This implies that there are still other predictors of academic performance besides ICT utilization and self-regulated learning which influences the academic performance of prospective teachers in University of Ilorin, Nigeria. In this wise, therefore, the Beta weight and t-values were computed in order to know the contribution of each of the independent variables, and the output reveals thus:

Table 13: Contributions of Information and Communication Technology utilization and Self-regulation on Academic Performance of Prospective teachers in University of Ilorin

\begin{tabular}{|c|c|c|c|c|c|}
\hline Model & $\mathbf{B}$ & $\begin{array}{r}\text { Std. } \\
\text { Error }\end{array}$ & Beta & Calculated t-value & Sig \\
\hline Constant & 3.019 & 0.229 & & 13.198 & 0.000 \\
\hline Academic ICT use & 0.042 & 0.009 & 0.197 & 4.786 & 0.000 \\
\hline Non-academic ICT use & 0.013 & 0.007 & 0.072 & 1.793 & 0.073 \\
\hline Elaboration & 0.015 & 0.006 & 0.124 & 2.373 & 0.018 \\
\hline Organization & 0.071 & 0.008 & 0.455 & 9.078 & 0.000 \\
\hline Critical thinking & 0.011 & 0.006 & 0.096 & 1.977 & 0.048 \\
\hline Metacognitive & 0.014 & 0.003 & 0.244 & 4.235 & 0.000 \\
\hline Peer learning & 0.09 & 0.008 & 0.057 & 1.072 & 0.284 \\
\hline Help seeking & 0.12 & 0.007 & 0.085 & 1.674 & 0.095 \\
\hline
\end{tabular}

Predictors: (Constant) Academic-oriented ICT use, Non-academic oriented ICT use,

Elaboration, Organization, Critical thinking, Metacognitive, Peer Learning, Help seeking

Dependent variable: Academic Performance of Prospective teachers in University of Ilorin, Nigeria

Table 13 shows the contributions of each independent variable (Academic-oriented ICT use, Nonacademic oriented ICT use, elaboration, organization, critical thinking, metacognitive, peer learning, help seeking) to academic performance. The beta weight indicates that academic-oriented ICT use contributed 0.197 , non-academic ICT use contributed 0.072 , elaboration contributed 0.124 , organization contributed 0.455 , critical thinking contributed 0.096 , metacognitive contributed 0.244 , peer learning contributed 0.057 while help seeking contributed 0.085 . The t-value further confirmed the contribution of the independent variables to the model. Organization contributed the highest t-value of 9.078, Academicoriented ICT use then followed suit with the t-value of 4.786, and this also implies that organization is the strongest predictor of academic performance of prospective teachers in University of Ilorin, Nigeria. This could be substituted in the Regression equation

$$
y=a+b_{1} x_{1}+b_{2} x_{2} b_{3} x_{3}+b_{4} x_{4}+b_{5} x_{5}+b_{6} x_{6}+b_{7} x_{7}+b_{8} x_{8},
$$

where

$$
\begin{aligned}
& \mathrm{b}_{1}=(\text { Academic-oriented ICT use })=0.197 \\
& \mathrm{~b}_{2}=(\text { Non-academic oriented ICT use }=0.072 \\
& \mathrm{b}_{3}=(\text { Elaboration })=0.124 \\
& \mathrm{~b}_{4}=(\text { Organization })=0.455 \\
& \mathrm{~b}_{5}=(\text { Critical thinking })=0.096 \\
& \mathrm{~b}_{6}=(\text { Metacognitive })=0.244 \\
& \mathrm{~b}_{7}=(\text { Peer learning })=0.057 \\
& \mathrm{~b}_{8}=(\text { Help seeking })=0.085
\end{aligned}
$$




$$
\begin{aligned}
& \mathrm{a}=\text { constant }(\text { Academic performance })=3.019 \\
& \mathrm{x}_{1} \mathrm{x}_{2} \mathrm{x}_{3} \mathrm{x}_{4} \mathrm{x}_{5} \mathrm{x}_{6} \mathrm{x}_{7} \text { and } \mathrm{x}_{8}=\text { slope of the curve } \\
& \mathrm{y}=3.019+0.197 \mathrm{x}_{1}+0.072 \mathrm{x}_{2}+0.124 \mathrm{x}_{3}+0.455 \mathrm{x}_{4}+0.096 \mathrm{x}_{5}+0.244 \mathrm{x}_{6}+0.057 \mathrm{x}_{7}+0.085 \mathrm{x}_{8}
\end{aligned}
$$

\section{Discussion}

The primary aim of this research was to investigate the relationship among Information Communication Technology utilization, self-regulated learning and academic performance among prospective teachers in University of Ilorin, Nigeria and to determine if gender had any influence on Information Communication Technology utilization, self-regulated learning and academic performance. The first research question, which was analyzed using rank order revealed that the level of Information Communication Technology utilization among the prospective teachers covered by this study was high. Specifically, the respondents utilize ICTs for academic-oriented purposes (completion of assignments, sending/receiving course materials, corroboration with classmates on academic-related matters, downloading learning materials, accessing relevant academic-related information, researchrelated activities, and presentation of class work) and non-academic oriented purposes (social networking, listening to music, gaming, watching movies and news). This finding may be attributed to the pervasiveness of ICT facilities among students in University of Ilorin, Nigeria. For instance, prospective teachers utilize ICTs for learning and assessment purposes regardless of the course of study in line with the policy of the university on technology integration in education. Likewise, this finding may be due to the use of mobile technologies such as laptops, Tablet Pcs, Ipads and Smartphones by prospective teachers inside and outside the university premises for social networking and other purposes. Supporting the finding, Yot-Domonguez and Marcelo (2017) agreed that university students utilize ICT tools for diverse purposes. The agreement in these findings may be as a result of the pervasiveness of ICT tools among undergraduate students covered by both studies.

The level of academic performance among prospective teachers in University of Ilorin was presented in Table 5. Thus, 345(59.5\%) of the prospective teachers a high level of academic performance, $165(28.4 \%)$ had average level of academic performance while $70(12.1 \%)$ of the prospective teachers had a low level of academic performance. This finding may be attributed to the fact that prospective teachers in University of Ilorin are constantly aware of the need to maintain a good Grade Point Average (GPA) so as to advance from one academic level to other in order to avoid probation or expulsion related to poor academic performance. The level of self-regulation among prospective teachers in University of Ilorin is as shown in Table 6. Hence, it is apparent that the level of selfregulation among the respondents was high. This finding may be further explained by noting that the prospective teachers have a high level of academic performance due to the utilization of some effective strategies for performing a broad range of academic tasks and activities. Tavakolizadeh and Ebrahimi-Qavam (2011) made similar conclusion that self-regulated learners actively take control of the learning process by being self-paced, self-directed and independent.

The $t$-test computation on the difference in the extent of utilization of Information Communication Technology among prospective teachers in University of Ilorin, Nigeria based on gender showed that gender did not in any way influence prospective teachers' utilization of ICT in University of Ilorin. This finding may be due to the fact that prospective teachers tend to have access to ICT facilities which are generally used for academic purposes and non-academic purposes. This finding is consistent with that of Efuwape, and Ayotola (2013) which reported no significant gender difference in both acceptability and usability of a computer package among University and Polytechnic students in Ogun State, Nigeria.Likewise, Chama and Sanjay (2016) made a similar conclusion that gender did not play a role in students and faculty opinions towards ICT use in Indian universities. However, it differs from Peter and Valkenburg's (2009) earlier finding that male students utilize ICT better than their female counterparts. Peter and Valkenburg's position may have been influenced by the sample for their study which was drawn from a population of adolescent internet users. It is possible that adolescents do not utilize several ICT to carry out a broad range of academic and non-academic tasks like prospective teachers in the University. 
The $t$-test computation on the difference in the level of academic performance among prospective teachers in University of Ilorin, Nigeria based on gender showed that gender did not in any way influence prospective teachers' academic performance in University of Ilorin. Thus, given that male and female prospective teachers in University of Ilorin are exposed to the same learning experiences and assessed commonly, irrespective of gender, it is possible that all prospective teachers work hard to maintain a good academic performance so as to complete a chosen course of study. This finding is in line with the finding of Abdu-Raheem (2012) and Josiah and Adejoke (2014) which revealed no significant differences in the academic performance of students based on gender. Nevertheless, this finding is at variance with the findings of Awofala (2011) which concluded that gender influences students' academic performance. This discrepancy in findings might be as a result of the experimental nature of the former study carried out among science students while the present investigation was a cross-sectional study among prospective teachers.

The $t$-test computation on the difference in the level of self-regulated learning among prospective teachers in University of Ilorin, Nigeria based on gender showed that gender did not in any way influence prospective teachers' adoption of self-regulation strategies in University of Ilorin. That is to say, male prospective teachers and their female counterparts have a high level of self-regulation. This finding may be attributed to the very demanding nature of the coursework of prospective teachers in University of Ilorin which requires some degree of control, self-direction, independence, critical thinking, peer learning, organization, elaboration, help seeking and metacognition from students. This finding corroborates the finding of Alotaibi, Tohmaz and Jabak (2017) which reported a positive and significant relationship between self-regulated learning and students' academic achievement at King Saud University. Nonetheless, Loong (2012) disagreed with the present finding by concluding that there was no significant relationship between self-regulated learning strategies and Mathematics performance of pre-university students in Malaysia. The disagreement in these findings may be as a result of the difference in the studentship status of the respondents covered by both studies.

The Pearson Product Correlation Coefficient (PPMC) computation on the relationship between Information and Communication Technology utilization and self-regulated learning of prospective teachers in University of Ilorin, Nigeria showed that there is a significant relationship between Information and Communication Technology utilization and academic performance of prospective teachers in University of Ilorin. This finding may be attributed to the integration of a broad spectrum of available and accessible Information Communication Technology tools to control and facilitate learning endeavours among prospective teachers in University of Ilorin. This finding is in line with that of Seyedeh and Masoud (2014) which found a direct relationship between ICT and self-regulation among undergraduate students of Islamic Azad University of Sari

The multiple regression computation on the composite relationship among Information Communication Technology utilization, self-regulated learning and academic performance of prospective teachers in University of Ilorin revealed a significant relationship. This finding could be explained by considering the fact that self-regulated learners may be better inclined to marshal the potentials of ICTs in a productive manner that improves their academic performance. In other words, the high level of ICT utilization and self-regulation among the prospective teachers covered by this study means that their academic performance may be significantly improved. Thus, this finding is in agreement with that of Kute and Pote-Palsamkar (2015) which reported a significant relationship between the self-regulated learning and internet usage of undergraduates in university of Mumbai. Substantiating the foregoing, Muhammed and Abubakar (2015) found that there is a significant relationship between SRL and academic achievement among undergraduate students in Malaysia. The findings of the present study also revealed that the use of organization as a self-regulated learning strategy was the strongest predictor of academic performance among prospective teachers in University of Ilorin while peer learning was the weakest predictor. In this sense, it is conceivable that prospective teachers exercise control over the process of learning by stipulating a scale of preference for the important tasks that are to be achieved in order to perform maximally in the teacher education programme. In a similar vein, academic-oriented use of ICT was found to be a strong predictor of academic performance among prospective teachers. That is to say, ICTs have the potential to enhance students' academic performance if properly utilized for pedagogic purposes. This finding supports the 
finding of Onyia (2013) which found that ICT significantly impacts students' academic studies in university of Nigeria Nsukka. However, this finding disagrees with the finding of Shamim, Jahangir and Ariful (2015) which reported that there is no significant relationship between the use of ICT and the performance of the students in private and public universities in Bangladesh. The differences in these findings may be due to the fact that the present study covered prospective teachers in a public Federal university in Nigeria.

\section{Conclusion}

The success of Nigerian educational system is a function of the availability of professional teachers that have been certified to practice after meeting all the academic and auxiliary requirements of the teacher education programmes that are commonly offered by a plethora of Colleges of Education and Universities. In view of this fact, the academic performance of prospective teachers is of great importance to the process of maintaining a sustainable educational system in Nigeria. To this end, therefore, the present study was carried out to investigate the relationship among Information Communication Technology utilization, self-regulated learning and academic performance among prospective teachers in University of Ilorin, Nigeria. The study concluded that prospective teachers utilize ICTs for academic-oriented purposes (completion of assignments, sending/receiving course materials, corroboration with classmates on academic-related matters, downloading learning materials, accessing relevant academic-related information, research-related activities, and presentation of class work) and non-academic oriented purposes (social networking, listening to music, gaming, watching movies and news).The level of ICT utilization, self-regulated learning and academic performance of prospective teachers in University of Ilorin was found to be high. Further, the study concluded that gender did not in any way influence the ICT utilization, self-regulated learning and academic performance of prospective teachers in University of Ilorin. On the whole, it was discovered that there is a significant composite relationship between the predictor variables (Information and Communication Technology utilization and self-regulated learning) and academic performance of prospective teachers in University of Ilorin. Thus, the two variables have a good relationship with the academic performance of prospective teachers.

\subsection{Recommendations}

Based on the findings of this study, the following recommendations are advanced:

1. Self-regulation training and seminars should be organized for prospective teachers in University of Ilorin in order to enable them adopt such strategies as organization, elaboration, metacognition, critical thinking and help seeking to make the best of the teaching-learning process.

2. Information Communication Technology should be properly harnessed for academic purposes among students and lecturers especially the use of social networking for academic related activities.

3. Intervention programmes to enhance ICT utilization, self-regulation and academic performance by Educational Psychologists, Counsellors and Educational Technologists should not be gender biased.

4. There is a need for more studies to investigate other factors apart from Information Communication Technology utilization and self-regulation that may mediate the academic performance of prospective teachers.

\section{References}

[1] Abdu-Raheem, B. O. (2012). The influence of gender on secondary school students' academic performance in South-West, Nigeria. Journal of Social Sciences, 31 (1), 93-98.

[2] Adegunju, K.A., Onivehu, A.O., Odetunde, A.O. \& Oyeniran, A.O. (2017). Cognitive and Psychosocial Predictors of Academic Achievement among Pre-Service Teachers in University of Ilorin, Nigeria. Asia Pacific Journal of Multidisciplinary Research, 5(3), 84-92 
[3] Al Asmari, A. A., \& Ismail M. N. (2012). Self-Regulated learning Strategies as Predictors of Reading Comprehension among Students of English as a Foreign Language. International Journal of Asian Social Science, 2(2), 178-201.

[4] Al-Khatib, S. A. (2010). Meta-cognitive self-regulated learning and motivational beliefs as predictors of college students' performance. International Journal of Research in Education, (27), 57-72.

[5] Alotaibi, K., Tohmaz, R. \& Jabak, O. (2017). The relationship between Self-Regulated Learning and academic achievement for a sample of community college students at King Saud University. Education Journal. 6(1), 28-37. doi: 10.11648/j.edu.20170601.14

[6] Arinze, F. O., Okonkwo, E. N. \&Iwunor, A. N., (2012). Information and Communication Technology (ICT) Application in Secondary Schools and Students' Academic Performance in Social Studies. International Multidisciplinary Journal, Ethiopia, 6 (4), 266-278. doi: http://dx.doi.org/10.4314/afrrev.v6i4.18,

[7] Ary D., Jacobs C. L., Razavieh A., \& Sorensen C. (2009). Introduction to Research in Education (8th Edition). Cengage Learning, Inc, Canada.

[8] Awofala, A. O. A. (2011). Effect of concept mapping strategy on students' achievement in junior secondary school mathematics. International Journal of Mathematics Trends and Technology, 2 (2), 11-16.

[9] Babaheidari, S. M., \&Svensson, L. (2014, October). Managing the Digitalization of Schools: an exploratory study of school principals' and IT managers' perceptions about ICT adoption and usefulness. In E-Learn: World Conference on E-Learning in Corporate, Government, Healthcare, and Higher Education, pp. 106-113.

[10] Balanskat, A., Blamire, R., \&Kafal, S. (2007). The ICT impact report: A review of studies of ICT impact on schools in Europe. Brussels: European Commission.

[11] Barrow, L. Markman, L. and Rouse, C. (2009). "Technology's Edge: the educational benefits of computer-Aided Instruction", The American Economic Journal: Economic Policy, Vol. 1, $52-74$

[12] Bebetsos, E. \& Antoniou, P. (2008). University students' differences on attitudes towards computer use. Comparison with students' attitudes towards physical activity. Interactive Educational Multimedia, 17, 20-28.

[13] Beena, M.A. (2012) A study on the ICT awareness of M.Ed. trainees. International Journal of Business Management \& Economic Research, 3(4), 573-578.

[14] Bidjerano, T. (2005). Gender differences in self-regulated learning. Paper presented at the Annual Meeting of the Northeastern Educational Research Association, October 19-21, Kerhonkson, NY, USA.

[15] Bhukuvhani, C., Zezekwa, N., \& Sunzuma, G. (2013). Students' Preparedness to Integrate Information and Communication Technology Tools and Resources for the Learning of Organic Chemistry. International Journal of Education and Development using Information and Communication Technology (IJEDICT), 7(2), 27-37.

[16] Chama, V., \& Sanjay, D. (2016). Gender difference towards Information Communication Technology awareness in Indian universities. Springer Plus, 5(370), doi: 10.1186/s40064$\underline{016-2003-1}$

[17] Cruz-Jesus, F., Vicente, M. R., Bacao, F., \& Oliveira, T. (2016). The education-related digital divide: An analysis for the EU-28. Computers in Human Behavior, 56, 72-82.

[18] Efuwape, B.M, \& Ayotola, A. (2013). Gender Differences in Acceptability and Usability of Computer Based Learning Package in Electrical and Electronics Technology in Nigeria. American Journal of Educational Research 1(10), 419-424. 
[19] Fadlelmula, F. K., Cakiroglu, E., \&Sungur, S. (2015). Developing a structural model on the relationship among motivational beliefs, self-regulated learning strategies, and achievement in mathematics. International Journal of Science and Mathematics Education, 13 (6), 13551375. doi:10.1007/s10763-013-9499-4

[20] Josiah, O., \&Adejoke, E. O. (2014). Effect of gender, age and mathematics anxiety on college students' achievement in algebra. American Journal Educational Research, 2 (7), 474-476.

[21] Hussaain, M. A., Iqbal, M. Z., \& Akhtar, M. S. (2010). Technology based learning environment and student achievement in English as a foreign language in Pakistan. Journal of World Academy of Science, Engineering, and Technology, 61, 129-133.

[22] Kute, M.P. \&Pote-Palsamkar, S. (2015). A study of relationship between internet usage and self-regulated learning of undergraduates. International Journal of Research-Granthaalayah, $5(4)$,

[23] Loong E. T. (2012). Self-Regulated Learning and their Effects on Math Performance of PreUniversity International Students in Malaysia. Journal of Education and Vocational Research,3(3), 89-97.

[24] Mbaeze, I.C., Ukwandu, E. \&Anudu, C. (2010). The influence of Information Communication Technologies on Students' Academic Performance. Journal of information Technology Impact. 10(3), 129-36

[25] Mlambo, V. (2011). An analysis of some factors affecting student academic performance in an introductory biochemistry course at the University of the West Indies. Caribbean Teaching Scholar. 1 (2), 79-92.

[26] Mohammed, T.A. \& Abdulghani, A.A. (2017). Impact of students' use of technology on their learning achievements in Physiology courses at the University of Dammam. Journal of Taibah University Medical Sciences, 12(1), 82-85

[27] Muhammad, A. S., \& Abu Bakar, N. (2015). Relationship of self-regulated learning and academic achievement among Universiti Sultan Zainalabidin (UNISZA) undergraduate students. International Conference on Empowering Islamic Civilization in the 21st Century, 67 September 2015 - Universiti Sultan ZainalAbidin, Malaysia.

[28] National Policy on Education (2013), Lagos: NERDC Press.

[29] Oluwagbohunmi, M. F. (2014). Gender issues in classroom interaction and students' achievement in social studies. International Journal Innovation Research Development, (5), 742-745.

[30] Onyia, M.N. (2013). The impact of ICT on University students' academic studies. Journal of Educational and Social Research, 3(8).

[31] Peng, C. (2012). Self- regulated learning behavior of college students of science and their academic achievement. Physics procedia, 33, 1446-1450.

[32] Peter, J., \& Valkenburg, P. (2009). Social consequences of the internet for adolescents: A decade of research. Psychological Science, 18(1), 1-4. doi:10.1111/j.1467-8721.2009.01595

[33] Rosen, L. D., Carrier, M., \& Cheever, N. A. (2013). Facebook and texting made me do it: Media-induced task-switching while studying. Computers in Human Behavior, 29, 948-958.

[34] Saffari, Z. F., \&Takmil, R. Arabzadeh (2014), The role of educational technology in medical education. Journal of Adavnced Medical Education Professionals, 2 (4), 183-

[35] Salako, E.A., Solomon, A.A. \& Muhammed, B.A. (2015). Perception of students on computer utilization and academic performance in the North-Central Geopolitical zone of Nigeria. I.J. Modern Education and Computer Science, (4), 53-60. DOI: 10.5815/ijmecs.2015.04.06 
[36] Samruayruen, B., Enriquez, J., Natakuatoong, O., Samruayruen, K. (2013). Self-Regulated Learning: A Key of a Successful Learner in Online Learning Environments in Thailand. Journal of Educational Computing Research. 48(1), 45-69.

[37] Seyedeh, H.H. \&Masoud, A. (2014). Understanding the relationship between ICT and selfregulated learning of Students of Islamic Azad University of Sari. International Journal of Economics, Management and Social Sciences, 3(12), 905-908

[38] Schunk, D. H., \& Zimmerman, B. J. (2008). Motivation and self-regulated learning: Theory, research and applications. New York: LEA.

[39] Shamim, Jahangir and Ariful (2015). The impact of ICT on students' performance: a case study on undergraduate university students. Manarat International University Studies, 4(1), $137-147$

[40] Stollak, M. J., Vandenberg, A., Burklund, A., \& Weiss, S. (2011). Getting social: The impact of social networking usage on grades among college students. In Proceedings from ASBBSAnnual Conference (pp. 859-865).

[41] Tavakolizadeh, J., \&Ebrahimi-Qavam S. (2011). Effect of teaching of self regulated learning strategies on self-efficacy in students. Procedia - Social and Behavioral Sciences 29, 1096 1104

[42] United Nations Development Programme (2017). Goal 4: "Quality education". Retrieved $8^{\text {th }}$ December, 2017.

[43] Voyer, D., \&Voyer, S. D. (2014). Gender Differences in Scholastic Achievement: A metaanalysis. Psychology Bulletin. 140 (4), 1174- 1204.

[44] Yot-Domínguez, C. \& Marcelo, C. (2017). International Journal of Educational Technology in Higher Education, (14)38, 1-18 https://doi.org/10.1186/s41239-017-0076-8

\section{Authors}

Onivehu Adams Ogirima, Department of Social Sciences Education, Faculty of Education, University of Ilorin, Ilorin, Nigeria, e-mail: adamsonivehu@gmail.com

Adegunju Kabir Adewale, Department of Counsellor Education, Faculty of Education, University of Ilorin, Ilorin, Nigeria, e-mail: kabeeradegunju78@gmail.com

Ohawuiro Onyinyechi Emilia, Department of Educational Technology, Faculty of Education, University of Ilorin, Ilorin, Nigeria, e-mail: emiliaohawuiro@gmail.com

Oyeniran Bunmi Juliana, Department of Social Sciences Education, Faculty of Education, University of Ilorin, Nigeria, bunmioyeniran@yahoo.com

\section{Acknowledgement}

Special thanks to the prospective teachers that participated in this study. We would also like to express our profound appreciation to the anonymous reviewers who laid the groundwork for the improvements and changes that were needed in this work. 
